\title{
Mites affecting hen egg production - some considerations for Brazilian farms
}

\author{
Ácaros de importância para a avicultura de postura - Algumas considerações \\ aplicadas à realidade da indústria avícola brasileira
}

\author{
Leandro do Carmo Rezende ${ }^{\mathrm{I}}$ Lucas Maciel Cunha ${ }^{\mathrm{I}}$ Cristina Mara Teixeira ${ }^{\mathrm{I}}$ \\ Paulo Roberto de Oliveira ${ }^{\mathrm{I}}$ Nelson Rodrigo da Silva Martins ${ }^{{ }^{*}}$
}

\begin{abstract}
The poultry industry is characterized for its constant search for productivity and profitability, which are based on flock health status. Brazilian Commercial laying hens (Gallus gallus domesticus) have been impacted significantly by mite infestations. This review aims to compile the literature on the occurrence, economic losses, biology, epidemiology and control of mite species considered important for the Brazilian laying poultry industry. The national experience was compared with practices of other countries and a scarcity of studies on this subject in Brazil was evident. The poultry industry has prioritized the use of pesticides to control infestations with little regard for the adverse effects. In this context, the integrated control programs using several strategies simultaneously constitute the best alternative to mite control. Integrated control programs involve measures of chemical, physical and biological nature, as well as attention to cultural aspects. However, studies should be performed aiming at the development of new control methods, evaluating the adequacy of practices developed in other countries to the national reality.
\end{abstract}

Key words: layer hen, mite, Dermanyssus, Megninia, Ornithonyssus.

\section{RESUMO}

A indústria avícola é caracterizada por sua constante busca por produtividade e lucratividade, que se relacionam diretamente ao status sanitário dos plantéis avícolas. No Brasil, as galinhas poedeiras (Gallus gallus domesticus) dos plantéis comerciais têm sido afetadas significativamente por infestações por ácaros. Esta revisão teve como objetivo a compilação da literatura existente sobre a ocorrência, perdas econômicas, biologia, epidemiologia e controle das espécies de ácaros consideradas importantes para a avicultura de postura brasileira. Nesse sentido, comparou-se a experiência nacional com a de outros países, observando-se escassez de estudos sobre o assunto no Brasil. Na indústria avícola brasileira, tem-se priorizado o uso de pesticidas para o controle das infestações, com pouca atenção para os efeitos negativos advindos. Nesse contexto, os programas de controle integrado, utilizando diversas estratégias simultaneamente, constituem uma alternativa adequada para o controle dos ácaros. Os programas de controle integrado envolvem medidas de natureza química, física e biológica, bem como a atenção a aspectos culturais. Entretanto, estudos adicionais devem ser realizados, visando ao desenvolvimento de novos métodos de controle e a adequação de práticas desenvolvidas em outros países para a realidade nacional.

Palavras-chave: poedeira, ácaro, Dermanyssus, Megninia, Ornithonyssus

\section{INTRODUCTION}

The poultry industry is an activity of great economic importance to Brazil, occupying a prominent position in Brazilian agricultural and international trade context. In the last years, it was observed an increase in the participation of this sector in Gross National Product and Brazilian exports. The Brazilian egg production is mainly destined to the domestic market, and consumption is increasing significantly in recent years (FIGUEIREDO et al., 2012).

Ectoparasites are temporary or permanent skin dwellers to get food (skin, blood, lymph and skin appendices), heat and protection. Avian ectoparasites can be classified into two large groups. The first is represented by those who feed only on tegumental surface and epithelial attachments, such as feathers or dead skin cells. These may have low economic importance. The other group may cause higher impact,

IDepartamento de Medicina Veterinária Preventiva, Escola de Veterinária, Universidade Federal de Minas Gerais (UFMG), Av. Presidente Antônio Carlos, 6627, CP 567, 30123-970, Campus da UFMG, Belo Horizonte, MG, Brasil. E-mail: nrsmart@gmail.com.*Autor para correspondência. 
through spoliation (blood or lymph), irritation and more significant economic loss. (DE VANEY, 1986).

In modern industrial systems the layer hens are kept in confinement, with high animal density, what contributes to the occurrence of ectoparasites, such as mites. The impact of parasites on layer hens may be highly relevant, requiring the development and establishment of control programs to minimize economic losses. Among the impacts caused by ectoparasites to the hens, distress is derived from nuisance and spoliation from parasitism and possibly transmission of bacterial or viral agents. Poultry under stress could have high levels of glucocorticoids in serum, which can lead to reduction appetite and food intake, reduction of gonadal activity, cardiovascular alterations, low efficiency of the immune response and consequent increase in susceptibility to secondary diseases (AXTELL \& ARENDS, 1990).

Layer hen mites: biology and epidemiology

Among the species of mites described affecting the industrial egg production in Brazil, hematophagous mites as Dermanyssus gallinae (Acari: Dermanyssidae) (De Geer, 1778) known as Poultry Red Mite and Ornithonyssus sylviarum (Acari: Macronyssidae) (Canestrini \& Fanzago, 1877), known as Northern Fowl Mite, are of great importance. Ornithonyssus bursa (Berlese, 1888), the Tropical Fowl Mite, is considered less relevant in Brazil. In Brazil, these species of mites are popularly misclassified as "lice" by lay people. Actually, "lice" are taxonomically referred to ectoparasites of Class Insecta, Order Phthiraptera (Mallophaga) of several families, genera and species, which are biologically and epidemiologically different of mites and require specific control measures.

Other mites may be observed in the layer hens, although they are most often found in subsistence breedings such as the species of the Genus Megninia (Acari: Analgidae) (Mégnin, 1877), which has few reports in industrial chickens (TUCCI et al., 2005).

There are some differences between the biological cycles of these parasites, which influence the decision-making aiming effective the control. Compared aspects of the biology of the species and genera of mites are shown in table 1.

The dispersion of mites in industrial systems can occurs through the transit of personnel,

Table 1 - Aspects of biology of layer hens mites

$$
\text { Dermanyssus gallinae }{ }^{1} \quad \text { Ornithonyssus spp. }{ }^{2} \quad \text { Megninia spp. }^{3}
$$

Duration and instars of Life Cycle

\begin{tabular}{|c|c|}
\hline $\begin{array}{l}\text { Feeding } \\
\text { Habit }\end{array}$ & Hematophagous \\
\hline Habitat & $\begin{array}{l}\text { Remain the most part of the } \\
\text { time in the environment, } \\
\text { climbing at night into the } \\
\text { host body to perform the } \\
\text { necessary bloodmeal }\end{array}$ \\
\hline Hosts & $\begin{array}{l}\text { Chickens, other wild and } \\
\text { domestic birds, humans and } \\
\text { other mammals }\end{array}$ \\
\hline
\end{tabular}

Eggs, larvae, protonymphs, deutonymphs and adult. One week are required por complete the life cycle

Hematophagous

Complete their entire life cycle on the host and in some cases the oviposition can be made also on the environment

Chickens, other wild and domestic birds, humans and other mammals
Eggs, larvae, protonymphs, deutonymphs and adult

Feed of feathers

Remain throughout their life cycle on the host, living on the feathers

Birds like hens, parakeets, pigeons and turkeys

References: 1 - MAURER \& BAUMGÄRTNER, 1992; TUCCI et al.,1998. 2 - FACCINI, 1987; TUCCI et al., 1998. 3 - FLECHTMANN, 1985; TUCCI et al., 2005; HERNÁNDEZ et al., 2007

Ciência Rural, v.43, n.7, jul, 2013. 
objects and other contaminated materials shared among the poultry houses and facilities, and the contact with rodents and wild birds from the neighborhood (MULLENS et al., 2009).

Production losses

Poultry Red Mite parasitized chickens may show anemia and behavioral changes, such as an increase in the frequency of pecking on feathers and feather grooming (KILPINEN et al., 2005). Moreover, this mite may cause decrease in egg production and egg viability and high mortality in young fowls. $\boldsymbol{D}$. gallinae can also act as a vector of viruses and bacteria (CUNHA, 2008), indicating an additional concern regarding its presence in poultry farms.

The Northern Fowl Mite is a serious threat in egg production (SOARES et al., 2008). The infested fowl may become stressed and weakened, with decreased feed consumption and egg production, reduction of seminal volume, weight loss, reduction in the half-life of erythrocytes and anemia, decreasing in profit of laying poultry farms. (DE VANEY, 1977; DE VANEY, 1979; SOARES et al., 2008; MULLENS et al., 2009). Decrease in egg production can reach fifty percent in severe infestations by $\boldsymbol{D}$. gallinae (FACCINI, 1987; FLETCHER \& AXTELL, 1991; SPARAGANO et al., 2009). A study conducted by VAN EMOUS (2005) estimated costs of around $€ 130$ million in controlling D. gallinae in European laying poultry industry. MULLENS et al. (2009), monitored caged egg-laying hens parasitized by $\boldsymbol{O}$. sylviarum for a period of ten weeks and estimated a reduction in profits of around US\$ 0.07 to 0.10 per fowl. In Brazil there are not studies on the economic losses caused by D. gallinae and Ornithonyssus spp.

The Poultry Red Mite is considered the most important ectoparasite for laying chicken industry in the world (SPARAGANO et al., 2009). Nevertheless there are few updated studies concerning its prevalence and epidemiology in laying hens in Brazil. In the United States $\boldsymbol{O}$. sylviarum is the hematophagous mite most commonly found, with a higher prevalence than $\boldsymbol{D}$. gallinae (DE VANEY, 1978). Other studies conducted in other countries around the world, estimated the $\boldsymbol{D}$. gallinae prevalence in poultry farms, which can vary from 30 to $90 \%$ (SPARAGANO et al., 2009). In a study conducted in forty-three Brazilian farms in São Paulo state, TUCCI et al. (1998) observed that eleven of them were infested by $\boldsymbol{D}$. gallinae, six by $\boldsymbol{O}$. sylviarum and fifteen for both species. Results suggest that $\boldsymbol{D}$. gallinae prevalence is greater than $\boldsymbol{O}$. sylviarum prevalence in São Paulo state. The scarcity of studies on the occurrence of these mites in Brazil, turns difficult the planning for adequate control strategies. However, considering the few studies conducted in Brazil and the information of other countries, may enable inferring that the hematophagous mite infestations are a significant sanitary problem for the poultry industry.

In relation to feather mites, there are few studies about the impact and occurrence in poultry industry. In a study conducted in Cuba, HERNÁNDEZ et al. (2006) showed that $89.6 \%$ of inspected laying farms were infested by Megninia ginglymura (Mégnin, 1877). In Brazil, Megninia ginglymura and Megninia cubitalis (Acari: Analgidae) (Mégnin, 1877) were reported causing economic losses in commercial farms in the state of São Paulo (TUCCI et al., 2005). Authors reported that the parasitized hens developed allergic reactions with itching, which eventually favored the occurrence of pyoderma and reduced egg production in the order of $20 \%$. Results indicated that infestations by Megninia spp. may generate significant losses to poultry industry. In other regions, the situation is poorly known, requiring investigation.

\section{Control of laying chicken mites}

In intensive commercial production systems the control of ectoparasites depends on management of equipment, food and water supply and on farm facilities. In Brazil, amongst several controlling strategies, the most recommended is the 'integrated control', which employs methods of chemical and non-chemical nature for combating various species of ectoparasites (FACCINI, 1987). These measures include periodic monitoring for the occurrence of infestation and prevention through biosafety, avoiding the proximity of wild birds through wire mesh fencing, prevent the entry of infested chickens, rodent control, use of pesticides and cleaning of equipment, eggs and their packaging and people and their clothes (MUL et al., 2009). However, some steps are only applicable to certain species of mites, due to biology and behavior peculiarities. According to the habitat and biology of some ectoparasites, spraying of some pesticides, for example, must be made on the hens or in the environment. Such knowledge enables knowing that certain types of trap are only effective against some species of parasites. This knowledge is essential for success of control measures.

Spraying of pesticides at high pressure is widely used such as mite infestations control measures (CHAUVE, 1988). In Brazil there are few studies on the use of pesticides to combat mites in the poultry 
Table 2 - Pesticides available in brazilian market to layer chicken mites control

\begin{tabular}{|c|c|c|c|}
\hline Active principle & Commercial name & Target & $\begin{array}{l}\text { Prescriptions of use according to } \\
\text { manufacturer }\end{array}$ \\
\hline Thrichlorfon $^{1}$ & $\begin{array}{l}\text { Triclorsil }^{\circledR} \text {, Tricorvet }{ }^{\circledR} \text { and } \\
\text { Ciclorson pó }^{\circledR}\end{array}$ & D. gallinae & $\begin{array}{l}\text { Spraying of the body surface of } \\
\text { the hens, repeating the application } \\
\text { again after } 7 \text { days }\end{array}$ \\
\hline Propoxur $^{2}$ & Bolfo ${ }^{\circledR}$ and Propoxur $1 \%{ }^{\circledR}$ & $\begin{array}{l}\text { D. gallinae, Ornithonyssus } \\
\text { spp. and Megninia spp. }\end{array}$ & $\begin{array}{l}\text { Spraying of the body surface of } \\
\text { the hens and the environment }\end{array}$ \\
\hline Carbaryl $^{2}$ & Farmaril $^{\circledR}$ & $\begin{array}{l}\text { D. gallinae, Ornithonyssus } \\
\text { spp. and Megninia spp. }\end{array}$ & $\begin{array}{l}\text { Spraying of the body surface of } \\
\text { the hens and the environment }\end{array}$ \\
\hline Permethrin technical $^{3}$ & Piolhaves $^{\circledR}$ & $\begin{array}{l}\text { D. gallinae, Ornithonyssus } \\
\text { spp. and Megninia spp. }\end{array}$ & $\begin{array}{l}\text { Spraying of the body surface of } \\
\text { the hens and the environment }\end{array}$ \\
\hline Cypermethrin technical $^{3}$ & Ectrin $^{\circledR}$ & D. gallinae & $\begin{array}{l}\text { Spraying of the body surface of } \\
\text { the hens and the environment }\end{array}$ \\
\hline Carbaryl $^{2}$ and cyperpethrin ${ }^{3}$ & Talfon top ${ }^{\circledR}$ & $\begin{array}{l}\text { D. gallinae, Ornithonyssus } \\
\text { spp. and Megninia spp. }\end{array}$ & $\begin{array}{l}\text { Spraying of the body surface of } \\
\text { the hens and the environment }\end{array}$ \\
\hline
\end{tabular}

Chemical class of pesticides: 1- Organophosphate ; 2- Carbamate; 3-Pyrethroid

industry. In table 2, a list of the main pesticides used for the mites control in poultry industry is shown, which are registered at the Brazilian Ministry of Agriculture, Livestock and Supply (MAPA). These Data were obtained in the Compendium of Veterinary Products (CPVS - SINDAN), which is available in the National Syndicate of Industry of Products for Animal Health webpage (SINDAN - COMPÊNDIO DE PRODUTOS VETERINÁRIOS). These products are available in the Brazilian market as well as its prescriptions use informations. The vast majority of substances are used empirically by veterinarians and other professionals of the layer hens farms. In some farms certain chemicals designed to the control of cattle ectoparasites are inappropriately used to combat poultry pests. Moreover, there is no specific regulation on the occurrence of residues in eggs.

Most of the studies involving chemical agents on the control of mite infestations are based on other countries research. Regarding $\boldsymbol{O}$. sylviarum, CRYSTAL \& DEMILLO (1988) reported sensivity to organophosphates. FLETCHER \& AXTELL (1991) reported the use of several products such as carbamates, pyrethroids and organophosphates, in an attempt to control hematophagous mites in poultry houses. The authors recommended the necessity of spraying the product onto the body surface of birds, since $\boldsymbol{O}$. sylviarum remain its entire life cycle on the host. Concerning D. gallinae, more than 35 chemical compounds were described for its control (CHAUVE, 1998). The pesticide should be selective and able to penetrate hiding cracks, must be spread on facilities after washing and disinfecting, especially for shared equipment. This prescription is due to the fact that the mite remains the most part of the time in the environment. In automated systems in laying poultry, cracks in egg collecting mats may serve as hiding place for mites, which can be crushed, enabling external contamination of eggs with blood. KIRKWOOD (1966) observed that the oral administration of single doses of 200-400 $\mathrm{mg} \mathrm{kg}^{-1}$ of Carbaryl against $\boldsymbol{D}$. gallinae maintained blood antiparasitic toxicity in fowls for up to two days. However, systemic treatment should be continued for a period of 10 to 17 days to ensure that all mites and their progeny feed the blood containing the acaricide. The spraying of Carbaryl $0.5 \%$ in chickens and facilities was also mentioned as an alternative for the control of $\boldsymbol{D}$. gallinae in brazilian poultry farms (TUCCI et al., 1998). OBA et al. (1982) refer to Permethrin $0.05 \%$ (spray) as effective in control of infestations by $\boldsymbol{D}$. gallinae. In Brazil, HAMANN (1990) evaluated in vitro sensitivity of $\boldsymbol{D}$. gallinae to acaricides such as organophosphates, pyrethroids and amidine, determining the $50 \%$ lethal dose and noted that the Organophosphorous products performed better than pyrethroids.

In Brazil there are no studies regarding effectiveness of chemicals on the control of Megninia spp. (TUCCI et al., 2005). Studies reported poultry immersion in a solution of Deltamethrin $0.4 \%$, spraying the installations with Malathion and Parathion powder application 
on the litter of poultry houses in India (D'SOUZA et al., 2001). LARRAMENDY et al. (2003) report the use of Cypermethrin 1.2\% on the control of mites in poultry establishments in Cuba.

Although many of acaricides are effective, aspects as food and environmental safety should be considered. In addition to the environmental impact, the use of these products can result in toxicity to poultry, in health hazard to the poultry industry workers and risk for egg consumers (TUCCI et al. 1998; SOARES et al. 2008). Failures in efficacy of the treatment may occasionally be due to inappropriate formulations, precarious application equipment, limitations of the chemical agent to reach the parasite, type of facilities, management of flocks and resistance development. Improper use of chemicals as a result of lack of training, such as ignoring the application recommendations for specific susceptible instars of the life cycle (egg, larva, nymph or adult) are also a possible cause of failure in the use of pesticides. It is, therefore, recommended testing for resistance and sensitivity of mites to pesticides, previously to use of chemicals in poultry houses and hens (CRYSTAL \& DEMILLO, 1988).

Studies show that the use of chemicals is an important tool in combating laying hen mites, especially pyrethroids and organophosphates. Therefore, research should be performed in Brazil in order to develop better strategies for use of chemicals in mite control. These studies should be based on scientific evidence and field experience of local veterinarians and professionals from abroad, although adapted to the regional reality, especially as the environmental, climatic and economic aspects will vary.

New approaches for mites control

The search for alternative methods of control, without the use of chemical intervention, has been a worldwide trend in the agricultural and veterinary area, seeking better food quality (MORRONE et al., 2001). Other methods of mite control are being utilized or developed, which may be associated to integrated control. Among these, mineral oil or vegetable extracts spraying, the use of traps for mites capture and the employment of silica, are alternatives of lower toxic impact. SOARES et al. (2008) reported the spraying of poultry with Neem extract at $2 \%$ to control $\boldsymbol{O}$. sylviarum infestations, requiring at least three weekly applications for effectiveness. MORRONE et al. (2001) performed laboratory essays, demonstrating sensivity of $\boldsymbol{D}$. gallinae to genus Coffea extracts In 2007, KIM et al. tested methanol extracts of 40 plants, noting acaricidal activity of some extracts, with similar efficiency as compared to fifteen acaricide principles currently in used. LARRAMENDY et al. (2003) reported the use of Neem oil at 2 to 3\%, for control of mites of genus Megninia in Cuba, obtaining strategic control success.

The use of mineral oil had been described as an alternative for the control of mite infestations in poultry (GUIMARÃES \& TUCCI, 1992; TUCCI et al. 1998). MAURER et al. (2009) reported that its use may reduce the survival of $\boldsymbol{D}$. gallinae. GUIMARÃES \& TUCCI (1992) described that refined mineral oil has an efficient acaricide action. In order to obtain an effective control, authors recommended that the mineral oil should be applied pure and only in mite clumps and a new application must be made within eight days after the first treatment. Some authors also note that the use of silica (silicon dioxide) reduces the population of hematophagous mites due to death caused by dehydration (KIRKWOOD, 1974; CHAUVE, 1998) and by locking joint functions, preventing the movement of the mite. MAURER et al. (2009) also found that the silica inhibits the reproduction of $\boldsymbol{D}$. gallinae. Mineral oil and silica are low cost products and commercially available in Brazil, enabling their recommendation. It is suggested that they should be used concurrently with other methods, such as spraying of pesticides. Moreover, other practices related to integrated control should be adopted in order to avoid mite dispersion into the poultry houses.

Traps can also be used for control of D. gallinae, to evaluate mite population density and resistance (CHAUVE, 1998). CHIRICO and TAUSON (2002), reported the use of traps containing metrifonate at $2 \%$, revealing that traps placed on mite hidings, away from fowl, resulted in reductions of 95 to $99 \%$ in populations of hematophagous mites. CUNHA (2008) has studied compounds related to chemical ecology of $\boldsymbol{D}$. gallinae such as allelochemicals and pheromones, searching for attracting substances in traps. These substances could enhance the efficiency of traps, which combined with other control methods, could lead to improved integrated pest management programs, although field trials are important for validation. However, the use of trap is not indicated for Ornithonyssus spp. and Megninia spp. infestations control since these mites do not lives on the environment.

The biological control, such as predation by arthropods of the Order Dermaptera (GUIMARÃES et al., 1992) has been evaluated. Considering that poultry manure may be an environment for the proliferation 
of these predators, it may of importance to maintain some, although minimized, for the maintenance of natural predators, preserving arthropods important in the biological control of mites (AXTELL \& ARENDS, 1990). Alternative methods related to biological control, may involve the use of entomopathogens such as bacteria (Bacillus thuringiensis and Bacillus nigateria israelensi) and fungi (Beauveria bassiana and Trichoderma album) (SELL et al., 1970; CHAUVE, 1998; KAOUD, 2010). The development of vaccines against hematophagous mites has been the focus of recent research around the world, with the possibility of being an important perspective to the future control of D. gallinae (MUL et al., 2009).

\section{CONCLUSION}

Mite infestations have resulted in relevant negative impacts to the poultry industry, especially egg laying chickens. In Brazil, few studies on prevalence, impacts, economic damages and combat measures are available. Research must be conducted to develop new strategies, which should be adapted to local poultry industry context. The control of mite infestations requires adequate technical knowledge about the biology, behavior and prevention. For the implementation of integrated control, aspects related to the management and operation of poultry farms must be reviewed and monitored, including personnel awareness. Strategies should consider specific characteristics of each production system and should be continuously reevaluated during the year. The control strategies must be monitored and reviewed periodically, considering possible avian, environmental and human impacts.

\section{ACKNOWLEDGEMENTS}

The authors are grateful to Conselho Nacional de Desenvolvimento Científico e tecnológico (CNPq), Fundação de amparo à Pesquisa de Minas Gerais (FAPEMIG) and to Comissão de

Aperfeiçoamento de Pessoal (CAPES).

\section{REFERENCES}

AXTELL, R.C.; ARENDS, J.J. Ecology and management of arthropod pests of poultry. Annual Review of Entomology, v.35, p.101-126, 1990. Disponível em: <http://birdflubook.com/ resources/Axtell_1990_ARE_35_101.pdf >. Acesso em: 23 abr. 2012.

CHAUVE, C. The poultry red mite Dermanyssus gallinae (De Geer, 1778): current situation and future prospects for control. Veterinary Parasitology, v.79, n.8, p. 239-245, 1998. Disponível em: <http://dx.doi.org/10.1016/S0304-4017(98)00167-8>. Acesso em: 30 abr. 2012. doi: 10.1016/S0304-4017(98)00167-8.
CHIRICO, J.; TAUSON, R. Traps containing acaricides for the control of Dermanyssus gallinae. Veterinary Parasitology, v.110, n.1-2, p.109-116, 2002. Disponível em: <http://dx.doi. org/10.1016/S0304-4017(02)00310-2>. Acesso em: 23 mar. 2012. doi: 10.1016/S0304-4017(02)00310-2.

CRYSTAL, M.M.; DEMILLO, A.B. Susceptibility of laboratoryreared northern fowl mites, Ornithonyssus sylviarum (Acari: Macronyssidae), to selected acaricides. Experimental and Applied Acarology, v.4, n.4, p.353-358, 1988. Disponível em: $<$ http://www.ncbi.nlm.nih.gov/pubmed/3168660>. Acesso em: 12 abr. 2012. doi: 10.1007/BF01275166.

CUNHA, L.M. Dermanyssus gallinae (Acari: Dermanyssidae) (De Geer, 1778): Colonização e resposta de protoninfas alimentadas a correntes de ar e a odores de extratos de ácaros co-específicos em olfatômetro discriminante. 2008. $32 \mathrm{f}$. Dissertação (Mestrado em Ciência Animal) - Curso de Pósgraduação em Ciência Animal, Universidade Federal de Minas Gerais, MG.

D’SOUZA, P.E et al. Feather mite infestation in a broiler breeder farm. Veterinary Record, v.149, n.25, p.777, 2001. Disponível em: <http://veterinaryrecord.bmj.com/content/149/25/777.1.citat ion>. Acesso em: 02 abr. 2012. doi: 10.1136/vr.149.25.777-a.

DE VANEY, J.A. A survey of poultry ectoparasite problems and their research in the United States. Poultry Science, v.57, n.5, p.1217-1220, 1978. Disponível em: <http://ps.fass.org/ content/57/5/1217.abstract>. Acesso em: 12 abr. 2012. doi: $10.3382 /$ ps.0571217.

DE VANEY, J.A. The effects of the northern fowl mite Ornithonyssus sylviarum on egg production and body weight of cage white leghorn hens. Poultry Science, v.58, n.1, p.191194, 1979. Disponível em: <http://ps.fass.org/content/58/1/191. abstract>. Acesso em: 23 mar. 2012. doi: 10.3382/ps.0580191.

DE VANEY, J.A. Ectoparasites. Poultry Science, v.65, n.4, p.649-656, 1986. Disponível em: <http://ps.fass.org/ content/65/4/649.abstract>. Acesso em: 23 mar. 2012. doi: $10.3382 /$ ps.0650649.

DE VANEY, J.A et al. Effect of the Northern Fowl Mite, Ornithonyssus sylviarum (Canestrini and Fanzago) on White Leghorn Roosters. Poultry Science, v.56, n.5, p.1585-1590,1977. Disponível em: <http://ps.fass.org/content/56/5/1585.abstract>. Acesso em: 23 mar. 2012. doi: 10.3382/ps.0561585.

FACCINI, J.L.H. Ácaros hematófagos: parasitos de aves de postura (Gallus gallus) no Brasil. Diversificação, biologia e controle. Arquivo Fluminense de Medicina Veterinária, v.2, n.1, p.29-31, 1987.

FIGUEIREDO, G.O. et al. Performance and egg quality of laying hens fed with dietary levels of digestible lysine and threonine. Arquivo Brasileiro de Medicina Veterinária e Zootecnia, v.64, n.2, p.743-750, 2012. Disponível em: <http://dx.doi.org/10.1590/ S0102-09352012000300028>. Acesso em: 02 nov. 2012. doi: 10.1590/S0102-09352012000300028.

FLECHTMANN, C.H.W. Ácaros de importância médicoveterinária. 3.ed. São Paulo: Nobel, 1985.192p.

FLETCHER, M.G.; AXTELL, R.C. Susceptibilities of northern fowl mite, Ornithonyssus sylviarum (Acarina: Macronyssidae), 
and chicken mite, Dermanyssus gallinae (Acarina: Dermanyssidae), to selected acaricides. Experimental and Applied Acarology, v.13, n.2, p.137-142, 1991. Disponível em: <http://rd.springer.com/article/10.1007/BF01193664>. Acesso em: 12 abr. 2012. doi: 10.1007/BF01193664.

GUIMARÃES, J.H.; TUCCI, E.C. Avaliação da eficiência do óleo mineral no controle do Dermanyssus gallinae (De Geer, 1778) (Acari: Dermanyssidae), em condições de campo e laboratório. Revista Brasileira de Entomologia, v.36, n.4, p.859-862,1992.

GUIMARÃES, J.H. et al. Dermaptera (Insecta) associados a aviários industriais no Estado de São Paulo e sua importância como agentes de controle biológico de pragas avícolas. Revista Brasileira de Entomologia, v.36, n.3, p.527-534, 1992.

HAMANN, W. Sensibilidade in vitro do Dermanyssus gallinae (De Geer, 1778) e Ornithonyssus sylviarum (Canestrini e Fanzago, 1877) (Acari: Gamasida) frente a acaricidas fosforados, piretróides e amidinas, com observações sobre o ciclo biológico. 1990. 42f. Dissertação (Mestrado em Ciências, em Medicina Veterinária - Parasitologia Veterinária). Curso de Pós-graduação em Medicina Veterinária, Universidade Federal Rural do Rio de Janeiro, RJ.

HERNÁNDEZ, M. et al. Ectoparasites diagnosed in laying hens from comercial farms in Cuba. Information of the presence of a new mite from the feathers: Megninia ortari (Acari Analgesidae). Revista Cubana de Ciencia Avícola, v.30, n.1, p.49-54, 2006. Disponível em: <http://www.iia.cu/rev2006_1.php>. Acesso em: 12 abr. 2012.

HERNÁNDEZ, M. et al. Dynamics of parasitic population: Megninia ginglymura Mégnin (Acari: Analgidae): modelling criteria. Revista Cubana de Ciencia Avícola, v.31, n.2, p.127134, 2007. Disponível em: <http://www.iia.cu/rev2007_2.php>. Acesso em: 12 abr. 2012.

KAOUD, H.A. Susceptibility of poultry red mites to entomopathogens. International Journal of Poultry Science, v.9, n.3, p.259-263, 2010. Disponível em: <http://www.pjbs. org/ijps/fin1671.pdf>. Acesso em: 18 maio, 2012. doi: 10.3923/ ijps.2010.259.263.

KILPINEN, O. et al. Dermanyssus gallinae and Ascaridia galli infections on behaviour and health of laying hens (Gallus gallus domesticus). British Poultry Science, v.46, n.1, p.2634, 2005. Disponível em: <http://www.tandfonline.com/doi/ abs/10.1080/00071660400023839 \#preview>. Acesso em: 02 abr. 2012. doi: 10.1080/00071660400023839.

KIM, S.I. et al. Contact and fumigant toxicity of oriental medicinal plant extracts against Dermanyssus gallinae (Acari: Dermanyssidae). Veterinary Parasitology, v.145, n.3-4, p.377-382, 2007. Disponível em: <http://dx.doi.org/10.1016/j. vetpar.2006.12.021>. Acesso em: 22 maio, 2012. doi: 10.1016/j. vetpar.2006.12.021.

KIRKWOOD, A.C. Control of poultry mites. British Poultry Science, v.8, n.1, p.75-80, 1966. Disponível em: <http://www. tandfonline.com/doi/abs/10.1080/00071666708415651\#previ ew>. Acesso em: 19 mar. 2012. doi:10.1080/00071666708415651.

KIRKWOOD, A.C. Sorptive dusts for the control of the poultry red mite Dermanyssus gallinae. International Pest Control, v.16, n.1, p.12-15, 1974. Disponível em: <http:// www.uzpi.cz/zpk_doc/eng/about_library.htm>. Acesso em: 16 maio, 2012

LARRAMENDY, R. et al. El Nim: sus productos naturales para el control de parásitos de las aves, coleópteros y larvas de la mosca doméstica. Revista Cubana de Ciencia Avícola, v.27, n.1, p.16, 2003. Disponível em: <http://www.iia.cu/rev2003_1.php>. Acesso em: 26 abr. 2012.

MAURER, V.; BAUMGÄRTNER, J. Temperature influence on life table statistics of the chicken mite Dermanyssus gallinae (Acari: Dermanyssidae). Experimental and Applied Acarology, v.15, n.1, p.27-40, 1992. Disponível em: <http://www.springerlink. com/content/jqxw590351423811>. Acesso em: 21 abr. 2012. doi: 10.1007/BF01193965

MAURER, V. et al. In vitro efficacies of oils, silicas and plant preparations against the poultry red mite Dermanyssus gallinae. Experimental and applied Acarology, v.48, p.31-41, 2009. Disponível em: <http://orgprints.org/15721/>. Acesso em: 21 abr. 2012. doi: 10.1007/s10493-009-9254-2.

MORRONE, F. et al. Ação acaricida de extratos foliares de espécies de Coffea (Rubiaceae) sobre Dermanyssus gallinae (De Geer, 1778) (Acari: Dermanyssidae). Arquivos do Instituto Biológico, v.68, n.2, p.43-47, 2001. Disponível em: <http://www.biologico.s p.gov.br/docs/arq/V68_2/morrone.pdf>. Acesso em: 19 abr. 2012.

MUL, A. et al. Control methods for Dermanyssus gallinae in systems for laying hens: results of an international seminar. World's Poultry Science Journal, v.659, n.4, p.589-600, 2009. Disponível em: <http://dx.doi.org/10.1017/S0043933909000403>. Acesso em: 28 abr. 2012. doi: 10.1017/S0043933909000403.

MULLENS, B.A. et al. Temporal changes in distribution, prevalence and intensity of northern fowl mite (Ornithonyssus sylviarum) parasitism in commercial caged laying hens, with a comprehensive economic analysis of parasite impact. Veterinary Parasitology, v.160, n.1-2, p.116-133, 2009. Disponível em: <http://www.ncbi.nlm.nih.gov/pubmed/19081198>. Acesso em: 22 mar. 2012. doi: 10.1016/j.vetpar.2008.10.076.

OBA, M.S.P. et al. Ensaio da ação acaricida de Permethrin sobre Dermanyssus gallinae (De Geer,1778) em condições de campo. Revista da Faculdade de Medicina Veterinária e Zootecnia da Universidade de São Paulo, v.19, n.1, p.35-37, 1982.

SELL, J.L. et al. Evaluation of a biological insecticide for control of poultry mites. Poultry Science, v.49, n.2, p.557-559, 1970. Disponível em: <http://ps.fass.org/content/49/2/557.abstract>. Acesso em: 03 maio, 2012. doi: 10.3382/ps.0490557.

SINDAN - COMPÊNDIO DE PRODUTOS VETERINÁRIOS. Disponível em: <http://www.cpvs.com.br/cpvs/pesquisa.aspx>. Acesso em: 02 nov. 2012.

SOARES, N.M. et al. Controle da infestação por Ornithonyssus sylviarum (CANESTRINI E FANZAGO, 1877) (ACARI: MACRONYSSIDAE) em poedeiras comerciais utilizando extrato de Azadirachta indica. Revista Brasileira de Parasitologia Veterinária, v.17, n.4, p.175-178, 2008. Disponível em: <http:// dx.doi.org/10.159 0/S1984-29612008000400001>. Acesso em: 23 maio, 2012. doi: 10.159 0/S1984-29612008000400001.

SPARAGANO, O. et al. Prevalence and key figures for the Poultry red mite Dermanyssus gallinae infections in poultry farm systems. Experimental and Applied Acarology, v.48, n.1-2, p.3-10, 
2009. Disponível em: <http://www.springerlink.com/content/ f725364320jv4424/>. Acesso em: 18 mar. 2012. doi: 10.1007/ s10493-008-9233-z.

TUCCI, E.C. et al. Ocorrência de ácaros hematófagos em aviários de postura no Estado de São Paulo, Brasil. Revista Brasileira de Parasitologia Veterinária, v.5, n.2, p.95-102, 1998. Disponível em: <http://cbpv.com.br/rbpv/documentos/711998/c7171_78. pdf $>$. Acesso em: 28 mar. 2012.
TUCCI, E.C. et al. Infestação por Megninia spp. em criação industrial de aves produtoras de ovos para consumo. Arquivos do Instituto Biológico, v.72, n.1, p.121-124, 2005. Disponível em: <http://www.biologico. sp.gov.br/docs/arq/V72_1/tucci1.PDF>. Acesso em: 27 mar. 2012.

VAN EMOUS, R. Wage war against the red mite. Poultry International, v.44, n.11, p.26-33, 2005. 